\title{
Aluminium Phosphide-induced Hepato-nephrotoxicity and Oxidative Damage in Rats: The Protective Effect of $\alpha$-lipoic Acid
}

\author{
Mokhtar I. Yousef, Naglaa F. Soliman*, Fatma M. El-Demerdash \\ Department of Environmental Studies, Institute of Graduate Studies and Research, Alexandria University, Alexandria, \\ Egypt
}

\begin{abstract}
The present experiment was carried out to investigate the effectivness of $\alpha$-lipoic acid in allevating the toxicity of aluminium phosphide on biochemical parameters, free radicals and enzyme activities in plasma, liver and kidney of male rats. Animals were orally treated with aluminium phosphide, $\alpha$-lipoic acid and their combination for 30 consecutive days. Treatment with aluminium phosphide led to significant decrease in plasma total protein and glucose and increase in transaminases, phosphatases, urea, creatinine and bilirubin. Treatment with aluminium phosphide significantly decreased glutathione S-transferase (GST), catalase (CAT) and reduced glutathione (GSH) in plasma, liver and kidney. While, thiobarbituric acid reactive substances (TBARS; as an index of lipid peroxidation) and superoxide dismutase (SOD) were increased in plasma, liver and kidney of rats treated with aluminium phosphide. Administration of $\alpha$-lipoic acid in combination with aluminium phosphide minimized and alleviated its toxic effects on most of the measured parameters. In conclusion, lipoic acid has beneficial effects and could be able to attenuate aluminium phosphide toxicity.
\end{abstract}

Keywords: Aluminium Phosphide, $\alpha$-Lipoic Acid, Antioxidants, Lipid peroxidation, Biochemical parameters, Rats.

\section{INTRODUCTION}

Aluminium phosphide is used as a pesticide and it is registered in many countries for the fumigation of agricultural commodities, animal feeds and processed foods [1]. It is liberally introduced into the environment for control of pests because of its efficiency, lack of persistence and harmless decomposition products [2]. Aluminum phosphide poisoning was reported in large numbers of victims from the North, Northwestern and Central parts of India [3] and Iran [4].

Toxic effects of aluminium phosphide are usually acute [5]. The clinical signs and symptoms accompained with acute aluminium phosphide exposure are attributed to the stongly poisonous phosphine gas which is liberated from the phosphide when it comes in contact with moisture present in air and leads to a multisystem involvement resulting in serious consequences [6].

Aluminium phosphide is a potent respiratory chain enzyme inhibitor. Its most important effect is the inhibition of cytochrome $\mathrm{c}$ oxidase. The inhibition of cytochrome $\mathrm{c}$ oxidase and other enzymes leads to the generation of superoxide radicals and cellular peroxides, and subsequent cellular injury through lipid peroxidation and other oxidant mechanisms [7]. It stimulates the production of hydrogen peroxide and reactive oxygen species, malonyldialdehyde (MAD), increases superoxide dismutase and inhibits

*Address correspondence to these authors at the University of Alexandria, Institute of Graduate Studies and Research, Department of Environmental Studies, 163 Horreya Avenue, P.O. Box 832, Alexandria 21526, Egypt; Tel: (0100) 4830165; E-mail: dr_naglaa.farag @yahoo.com catalase, peroxidase and glutathione [8,9]. Oxidative stress is one of the main mechanisms of action of aluminium phosphide toxicity [10].

Alpha lipoic acid is a popular cofactor of multienzymatic complexes which catalyzes the oxidative decarboxylation of $\alpha$-ketoacids. It satisfies almost all the characters of an "ideal antioxidant", being readily absorbed from the diet and rapidly converted to its redox couple, dihydrolipoic acid (DHLA) in many tissues. Both lipoic acid and DHLA effectively quench many types of free radicals $\left(\mathrm{RO}_{2}{ }^{-}, \mathrm{HOCl}, \mathrm{OH}^{*}, \mathrm{ONOOH}, \mathrm{O}_{2}^{-}\right.$, singlet oxygen) and this antioxidant activity can be displayed in both lipid and aqueous-cell compartments. They can also chelate redox active transition metals $(\mathrm{Fe}, \mathrm{Cu})$, preventing the production of ROS [11].

Animal studies suggest that glutathione, melatonin, vitamin $\mathrm{C}$, beta-carotene and possibly other antioxidants may play an effective role in allevating the effects of reactive oxidant species caused by phosphine gas [12]. On the other hand, the protective role of lipoic acid against aluminium phosphide induced negative changes in serum, liver and kidney biochemical, lipid peroxidation and enzymatic activities of male rats have not so far been fully understood. Therefore, the present work was carried out to investigate: (1) the alterations in biochemical parameters, free radicals and enzyme activities induced by aluminium phosphide in plasma, kidney and liver of male rats, (2) the role of lipoic acid in reducing the negative effects of aluminium phosphide, and (3) the effect of lipoic acid alone on the tested parameters. 


\section{MATERIALS AND METHODS}

\subsection{Chemicals}

Aluminium phosphide was purchased from Bernardo Quimca Comercio e Industria, formerly Casa Bernardo Ltda, Brazil. The molecular weight of this compound is 57.955 $\mathrm{g} / \mathrm{mol}$ with molecular formula of AlP. It is available as a tablet of $3 \mathrm{~g}$ that contains $56 \%$ AlP and $44 \%$ ammonium carbonate. Lipoic acid $\left(\mathrm{C}_{8} \mathrm{H}_{14} \mathrm{O}_{2} \mathrm{~S}_{2}\right)$ was purchased from Sigma Chemical Company (St. Louis, MO, USA). All other chemicals used in the experiment were of analytical grade. The tested dose of aluminium phosphide was $2 \mathrm{mg} / \mathrm{kg} \mathrm{BW}$. Dose response relationship of aluminium phosphide toxicity was determined as reported previously [13]. The dose of lipoic acid was $100 \mathrm{mg} / \mathrm{kg}$ BW and it was selected by Cakatay et al. [14].

\subsection{Animals and Administration Schedule of Aluminium Phosphide and Antioxidant}

Twenty eight male Wistar rats weighting 100-135 g were used in the present experiments. The local committee approved the design of the experiments, and the protocol conforms to the guidelines of the National Institutes of Health (NIH). Animals were housed seven per cage and kept on commercial diet and tap water provided ad libitum. After two weeks of acclimation, animals were divided into four equal groups ( 7 for each treatment group). The first group served as control. Groups 2, 3 and 4 were orally treated with Lipoic acid (100 mg/kg BW), aluminium phosphide (2 $\mathrm{mg} / \mathrm{kg} \mathrm{BW}$ ), and the combination of both aluminium phopshide (2 mg/kg BW) plus lipoic acid (100 mg/kg BW), respectively. Rats were orally administered their respective doses daily for 30 days. At the end of the experimental period animals were sacrificed by decapitation.

\subsection{Blood Collection and Tissue Preparation}

Blood samples were collected from the sacrificed animals and placed immediately on ice. Heparin was used as an anticoagulant and plasma samples were obtained by centrifugation at $860 \mathrm{xg}$ for $20 \mathrm{~min}$ and stored at $-60^{\circ} \mathrm{C}$ till measurements. Stored plasma samples were analyzed for the activities of antioxidant enzymes (glutathione S-transferase, GST; superoxide dismutase, SOD; catalase, CAT) and the markers of lipid peroxidation (thiobarbituric acid-reactive substances, TBARS).

Liver and kidney were immediately removed; weighed and washed using chilled saline solution. Tissues were minced and homogenized (10\%,w/v), separately, in ice-cold $1.15 \% \mathrm{KCl}-0.01 \mathrm{M}$ sodium, potassium phosphate buffer $(\mathrm{pH}$ 7.4) in a Potter-Elvehjem type homogenizer. The homogenate was centrifuged at $10,000 \mathrm{x} \mathrm{g}$ for $20 \mathrm{~min}$ at 4 ${ }^{\circ} \mathrm{C}$, and the resultant supernatant was stored at $-80{ }^{\circ} \mathrm{C}$ till analysis. Stored supernatant was used for the determination of enzyme activities, and the levels of TBARS, reduced glutathione (GSH) and protein content.

\subsection{Blood Biochemical Parameters and Enzyme Activities}

Stored plasma samples were analyzed for total protein by the Biuret method according to Henry et al. [15]. Plasma glucose, urea and creatinine concentrations were measured by the method of Trinder [16], Patton and Crouch [17] and Henry et al. [15], respectively. Plasma total bilirubin was measured using the method of Pearlman and Lee [18].

The activities of plasma enzymes were measured using the following methods: AST and ALT; Reitman and Frankel [19], AlP; Principato et al. [20], AcP; Moss [21], GST; Habig et al. [22]. CAT; Luck method involving the decomposition of hydrogen peroxide [23], SOD; Mishra and Fridovich [24] and Plasma thiobarbituric acid-reactive substances (TBARS) as described by the method of Tappel and Zalkin [25].

\subsection{Organs Biochemical Parameters and Enzyme Activities}

The resultant supernatant of the liver and kidney was used for measuring different enzyme activities, and the levels of free radicals according to the previous methods. Reduced glutathione (GSH) was determined according to Beulter et al. [26]. Tissue protein concentration was assayed by the method of Lowry et al. [27].

\subsection{Statistical Analyses}

The statistical analyses were performed using the SPSS10 package (release 3, SPSS Imc., Chicago III) running on MCROVAX 3500. One-way ANOVA test was used to compare the means of the different parameters of the different studied groups. A difference was considered significant at $\mathrm{p}<0.05$.

\section{RESULTS}

3.1. Effect of Lipoic Acid, Aluminium Phosphide and their Combinations on Enzyme Activities and Lipid Peroxidation

Results indicated that TBARS concentration was significantly $(p<0.05)$ increased, while GST activity was significantly $(p<0.05)$ decreased in plasma, liver and kidney of rats treated with aluminium phosphide (Table 1). Treatment with lipoic acid alone did not cause any changes in the activity of GST in plasma, liver and kidney compared with control group. Coadminstration of lipoic acid with aluminium phosphide significantly $(p<0.05)$ increased the activity of GST as compared with aluminium phosphide group. In addition, the presence of lipoic acid with aluminium phosphide caused a reduction in the elevation of plasma and tissue TBARS.

Data presented in Table 1 indicated that treatment with lipoic acid alone did not cause any significant effect on GSH compared to control group. While, treatment with aluminium phosphide significantly $(p<0.05)$ decreased GSH concentration in the liver.

The present results showed significant $(p<0.05)$ increase in SOD activities in plasma, liver, and kidney, while CAT activity significantly $(p<0.05)$ decreased compared with control group (Table 1). On the other hand, treatment with lipoic acid alone did not cause any significant changes in SOD and CAT activities in plasma, liver, and kidney (Table 1). Coadminstration of lipoic acid with aluminium phosphide significantly $(p<0.05)$ decreased the levels of 
Table 1. TBARS and the activities of GST, CAT and GSH of male rats treated with lipoic acid (LA), aluminium phosphide (AI. Ph.) and their combination.

\begin{tabular}{|c|c|c|c|c|}
\hline \multirow{2}{*}{ Parameter } & \multicolumn{4}{|c|}{ Experimental groups } \\
\hline & Control & Lipoic acid & Aluminium phosphide & $\mathbf{L A}+\mathbf{A l} . \mathbf{P h}$. \\
\hline \multicolumn{5}{|l|}{ Plasma } \\
\hline TBARS (nmol /ml) & $1.11 \pm 0.04^{\mathrm{b}}$ & $1.05 \pm 0.01^{\mathrm{b}}$ & $1.39 \pm 0.08^{\mathrm{a}}$ & $1.12 \pm 0.04^{\mathrm{b}}$ \\
\hline $\mathrm{GST}(\mu \mathrm{mol} / \mathrm{hr} / \mathrm{ml})$ & $0.96 \pm 0.03^{\mathrm{a}}$ & $0.95 \pm 0.05^{\mathrm{a}}$ & $0.81 \pm 0.02^{\mathrm{b}}$ & $0.92 \pm 0.03^{\mathrm{a}}$ \\
\hline $\mathrm{CAT}\left(\mu \mathrm{molH}_{2} \mathrm{O}_{2} / \mathrm{min} / \mathrm{ml}\right)$ & $69.4 \pm 5.65^{\mathrm{a}}$ & $71.2 \pm 3.68^{\mathrm{a}}$ & $55.5 \pm 5.39^{\mathrm{b}}$ & $70.0 \pm 5.15^{\mathrm{a}}$ \\
\hline $\mathrm{SOD}(\mathrm{U} / \mathrm{ml})$ & $0.83 \pm 0.04^{\mathrm{b}}$ & $0.83 \pm 0.04^{\mathrm{b}}$ & $1.04 \pm 0.05^{\mathrm{a}}$ & $0.84 \pm 0.05^{\mathrm{b}}$ \\
\hline \multicolumn{5}{|l|}{ Liver } \\
\hline TBARS (nmol /g tissue) & $27.0 \pm 0.45^{\mathrm{b}}$ & $26.3 \pm 0.66^{\mathrm{b}}$ & $36.6 \pm 0.59^{\mathrm{a}}$ & $27.2 \pm 1.55^{\mathrm{b}}$ \\
\hline GST $(\mu \mathrm{mol} / \mathrm{hr} / \mathrm{mg}$ protein $)$ & $1.14 \pm 0.03^{\mathrm{a}}$ & $1.15 \pm 0.04^{\mathrm{a}}$ & $0.98 \pm 0.02^{\mathrm{b}}$ & $1.13 \pm 0.01^{\mathrm{a}}$ \\
\hline SOD (U/mg protein) & $7.45 \pm 0.49^{\mathrm{b}}$ & $7.21 \pm 0.52^{\mathrm{b}}$ & $9.84 \pm 0.80^{\mathrm{a}}$ & $6.91 \pm 0.57^{b}$ \\
\hline $\mathrm{GSH}(\mu \mathrm{mol} / \mathrm{mg}$ tissue $)$ & $3.65 \pm 0.11^{\mathrm{a}}$ & $3.72 \pm 0.09^{\mathrm{a}}$ & $2.85 \pm 0.12^{\mathrm{b}}$ & $3.52 \pm 0.12^{\mathrm{a}}$ \\
\hline Catalase $\left(\mu \mathrm{molH}_{2} \mathrm{O}_{2} / \mathrm{min} / \mathrm{mg}\right.$ protein $)$ & $49.1 \pm 2.59^{\mathrm{a}}$ & $49.3 \pm 2.06^{\mathrm{a}}$ & $36.5 \pm 3.52^{\mathrm{b}}$ & $46.7 \pm 2.83^{\mathrm{a}}$ \\
\hline \multicolumn{5}{|l|}{ Kidney } \\
\hline TBARS (nmol /g tissue) & $17.3 \pm 0.67^{\mathrm{b}}$ & $16.3 \pm 0.40^{\mathrm{b}}$ & $20.9 \pm 0.53^{\mathrm{a}}$ & $17.1 \pm 0.05^{\mathrm{b}}$ \\
\hline GST $(\mu \mathrm{mol} / \mathrm{hr} / \mathrm{mg}$ protein $)$ & $0.98 \pm 0.02^{\mathrm{a}}$ & $1.01 \pm 0.05^{\mathrm{a}}$ & $0.83 \pm 0.03^{\mathrm{b}}$ & $0.97 \pm 0.01^{\mathrm{a}}$ \\
\hline SOD (U/mg protein) & $8.04 \pm 0.34^{\mathrm{b}}$ & $7.88 \pm 0.58^{\mathrm{b}}$ & $10.03 \pm 0.46^{\mathrm{a}}$ & $7.81 \pm 0.41^{\mathrm{b}}$ \\
\hline Catalase $\left(\mu \mathrm{molH}_{2} \mathrm{O}_{2} / \mathrm{min} / \mathrm{mg}\right.$ protein $)$ & $56.3 \pm 1.81^{\mathrm{a}}$ & $56.7 \pm 1.76^{\mathrm{a}}$ & $45.2 \pm 0.86^{\mathrm{b}}$ & $52.8 \pm 1.21^{\mathrm{a}}$ \\
\hline
\end{tabular}

Values are expressed as means $\pm \mathrm{SE} ; \mathrm{n}=7$ for each treatment group.

Mean values within a row not sharing a common supscript letter (a, b) were significantly different, $P<0.05$.

SOD and increased the levels of CAT as compared with aluminium phosphide group and returned to the values of control group.

Treatment with aluminium phosphide resulted in significant $(p<0.05)$ increase in plasma and liver AST, ALT, AcP and AlP activities compared with control (Tables 2 and 3). On the other hand, data showed that treatment with lipoic acid alone did not cause any changes in plasma or liver AST, ALT, AcP, while caused insignificant decrease in the activity of plasma AlP (Tables 2 and 3). Treatment with lipoic acid ameliorated the above mentioned changes induced by aluminium phosphide by affording considerable protection in maintaining the cellular integrity, as it is evident from the near normal activities of these marker enzymes in the plasma and hepatic tissue.

\subsection{Effect of Lipoic Acid, Aluminium Phosphide and their Combinations on Biochemical Parameters}

Data presented in Table 4 shows that treatment with aluminium phosphide caused a significant increase $(\mathrm{P}<0.05)$ in plasma urea, creatinine and bilirubin, while the levels of total protein and glucose were significantly decreased as compared to the control (Table 4). Treatment with lipoic acid alone caused insignificant decrease in plasma glucose, urea, creatinine, bilirubin and total protein levels. The presence of lipoic acid with aluminium phosphide maintained the levels of all above parameters closer to the normal levels (Table 4).

Table 2. Enzyme activities in plasma of male rats treated with lipoic acid (LA), aluminium phosphide (Al. Ph.) and their combination

\begin{tabular}{|l|c|c|c|c|}
\hline \multirow{2}{*}{ Enzymes } & \multicolumn{4}{|c|}{ Experimental groups } \\
\cline { 2 - 5 } & Control & Lipoic acid & Aluminium phosphide & LA + Al. Ph. \\
\hline \hline AST (U/l) & $46 \pm 1.06^{\mathrm{b}}$ & $47 \pm 1.06^{\mathrm{b}}$ & $56 \pm 0.84^{\mathrm{a}}$ & $48 \pm 0.60^{\mathrm{b}}$ \\
ALT (U/l) & $63 \pm 1.13^{\mathrm{b}}$ & $63 \pm 1.13^{\mathrm{b}}$ & $78 \pm 1.68^{\mathrm{a}}$ & $61 \pm 1.02^{\mathrm{b}}$ \\
AlP (U/l) & $180 \pm 14.22^{\mathrm{b}}$ & $171 \pm 8.54^{\mathrm{b}}$ & $223 \pm 11.71^{\mathrm{a}}$ & $181 \pm 13.53^{\mathrm{b}}$ \\
AcP (U/l) & $12.8 \pm 0.92^{\mathrm{b}}$ & $13.0 \pm 0.89^{\mathrm{b}}$ & $15.8 \pm 0.47^{\mathrm{a}}$ & $13.2 \pm 1.14^{\mathrm{ab}}$ \\
\hline
\end{tabular}

Values are expressed as means $\pm \mathrm{SE} ; \mathrm{n}=7$ for each treatment group.

Mean values within a row not sharing a common supscript letter (a, b, ab) were significantly different, $P<0.05$. 
Table 3. Enzyme activities in liver of male rats treated with lipoic acid (LA), aluminium phosphide (Al. Ph.) and their combination.

\begin{tabular}{|l|c|c|c|c|}
\hline \multirow{2}{*}{ Enzymes } & \multicolumn{4}{|c|}{ Experimental groups } \\
\cline { 2 - 5 } & Control & Lipoic acid & Aluminium phosphide & LA + Al. Ph. \\
\hline \hline AST $^{*} *$ & $94 \pm 1.13^{\mathrm{b}}$ & $96 \pm 0.96^{\mathrm{b}}$ & $109 \pm 2.11^{\mathrm{a}}$ & $94 \pm 0.73^{\mathrm{b}}$ \\
ALT $^{* *}$ & $81 \pm 1.57^{\mathrm{c}}$ & $82 \pm 1.60^{\mathrm{bc}}$ & $94 \pm 1.06^{\mathrm{a}}$ & $85 \pm 1.02^{\mathrm{b}}$ \\
AcP** & $18.58 \pm 0.32^{\mathrm{b}}$ & $18.86 \pm 0.69^{\mathrm{b}}$ & $23.26 \pm 0.69^{\mathrm{a}}$ & $18.89 \pm 0.94^{\mathrm{b}}$ \\
\hline
\end{tabular}

Values are expressed as means \pm SE; $\mathrm{n}=7$ for each treatment group.

Mean values within a row not sharing a common supscript letter (a, b, c, bc) were significantly different, $P<0.05$.

**IU/mg: international unit, the amount of the enzyme that under defined assay conditions will catalyse $1 \mathrm{~mol}$ of substrate $/ \mathrm{min} / \mathrm{mg}$ protein.

Table 4. Plasma biochemistry of male rats treated with lipoic acid (LA), aluminium phosphide (Al. Ph.) and their combination.

\begin{tabular}{|l|c|c|c|c|}
\hline \multirow{2}{*}{ Parameter (m/dl) } & \multicolumn{4}{|c|}{ Experimental groups } \\
\cline { 2 - 5 } & Control & Lipoic acid & Aluminium phosphide & LA + Al. Ph. \\
\hline \hline Total protein & $8.89 \pm 0.19^{\mathrm{ab}}$ & $9.51 \pm 0.37^{\mathrm{a}}$ & $7.49 \pm 0.13^{\mathrm{c}}$ & $8.73 \pm 0.29^{\mathrm{b}}$ \\
Glucose & $110.5 \pm 1.40^{\mathrm{a}}$ & $97.8 \pm 5.11^{\mathrm{ab}}$ & $93.6 \pm 4.64^{\mathrm{b}}$ & $111.1 \pm 8.77^{\mathrm{a}}$ \\
Bilirubin & $1.49 \pm 0.09^{\mathrm{b}}$ & $1.40 \pm 0.06^{\mathrm{b}}$ & $1.94 \pm 0.07^{\mathrm{a}}$ & $1.49 \pm 0.04^{\mathrm{b}}$ \\
Urea & $17.13 \pm 0.40^{\mathrm{b}}$ & $15.76 \pm 0.43^{\mathrm{b}}$ & $22.64 \pm 1.05^{\mathrm{a}}$ & $17.42 \pm 1.32^{\mathrm{b}}$ \\
Creatinine & $0.98 \pm 0.02^{\mathrm{b}}$ & $0.93 \pm 0.01^{\mathrm{b}}$ & $1.23 \pm 0.06^{\mathrm{a}}$ & $0.97 \pm 0.02^{\mathrm{b}}$ \\
\hline
\end{tabular}

Values are expressed as means \pm SE; $n=7$ for each treatment group.

Mean values within a row not sharing a common supscript letter $(\mathrm{a}, \mathrm{b}, \mathrm{c}, \mathrm{ab})$ were significantly different, $P<0.05$.

\section{DISCUSSION}

Caugh (1998) has reported that in the presence of aluminium phosphide cellular superoxide and peroxide radicals are generated, with subsequent cellular damage caused by lipid peroxidation [28]. Oxidative degradation of lipids known as lipid peroxidation, and other oxidant mechanisms damage biological macromolecules specially the cell membrane ultimately leading to cell death [29]. This is in agreement with our findings of significant increase in TBARS levels of plasma, liver and kidney of aluminium phosphide treated rats (Table 1). Significantly increased free radicals levels in aluminium phosphide-treatedis rats is in agreement with the results reported somewhere else [7, 8, 12]. Phosphine can trigger iron release from storage protein, increasing lipid peroxidation, leading to cell injury and/or cell death [30]. It has been proposed that free radicals, such as ROS, produced by phosphine are the basis of the observed genotoxicity in mammals, including exposed humans and mice [12]. The mechanism of phosphine induced lipid peroxidation could involve ROS generated from inhibition of cellular respiration, or a direct reaction between phosphine and $\mathrm{H}_{2} \mathrm{O}_{2}$ [31]. Additionally, the direct toxic effects of phosphine on myocardial cells can cause circulatory collapse. A direct relation to mortality has been suggested on the basis of superoxide dismutase (SOD), catalase and malonyldialdehyde levels on post mortem studies of aluminium phosphide poisoning patients [7].

Reduction in lipid peroxidation by lipoic acid may, at least partially, suppress the injury cascade induced by aluminium phosphide in rat plasma, liver and kidney. Thirunavukkarasu et al. [32] found a significant decreases in peroxidation indices namely lipid hydroperoxides, TBARS and conjugated dienes in liver and kidney of rats fed in lipoic acid with fructose. The activities of both enzymatic and nonenzymatic antioxidants were markedly elevated. Lipoic acid possibly reacts with free radicals that are prooxidants for ascorbic acid and tocopherol. Lipoic acid could maintain the intracellular redox balance, thereby offering a protective effect against free radical attack. Chugh, et al. [8] stated that ingestion of aluminium phosphide leads to a high superoxide dismutase activity and low catalase levels that result in formation of a high quantum of free radicals and accelerate lipid peroxidation. The latter, in turn, results in damage to cellular membrane, disruption of ionic barrier, nucleic acid damage and finally, cell death. In aluminium phosphide poisoned rats the levels of GSH levels are reduced in tested tissues, so the decrease in the activity of glutathione Stransferase observed in the present study may be partly due to the lack of its substrate GSH and also because of oxidative modification of its protein structure.

The present results showed that lipoic acid decreased oxidative stress induced by aluminium phosphide and this is in agrement with the obtained finding by Kokilavani et al. [33] who reported that lipoic acid plays an important role in allevating As induced oxidative damage by elevating the antioxidant status in the liver and kidney. Lipoic acid provided an additional mechanism for the direct removal of superoxide, thus sapring superoxide disumutase under conditions of increased reactive oxygen species [34]. Administration of lipoic acid interaperitoneally to the aged rats has led to the reduction in hydroxyl radicals and elevation in the level of glutathione. Thus, it can be claimed 
that lipoic acid can prevents the oxidation of reduced glutathione and protects its related enzymes from peroxidative damage [35]. Alpha lipoic acid has also been reported to assist the mitochondria's citric cycle; this in turn will increase the level of reduced glutathione, ATP, TCA cycle enzyme and electron transport chain complex activities [36-38].

The present study showed that aluminium phosphide caused liver damage which increased the activities of AST, ALT, AlP and AcP in both plasma and liver. Liver is one of the important target organs of phosphine poisoning in the human body [1]. After ingestion, phosphine gas is rapidly absorbed through the gastrointestinal tract and it is partly carried to the liver by the portal vein. Phosphine can cause liver dysfunction, especially after the first day of poisoning [39].

Lipoic acid supplementation with aluminium phosphide prevented the increased activities of liver enzymes, suggesting membrane protective effect [40]. Also, lipoic acid restored the activities of these enzymes suggesting the regulatory influence of the dithiols [41]. Treatment with lipoic acid enhances the above mentioned negatives effects induced by aluminium phosphide, by affording a considerable protection in maintaining the normal cellular integrity, as it is evident from the near normal activities of these marker enzymes in the plasma and hepatic tissue.

The accompained decrease in glucose level of rats treated with aluminium phosphide are in accordance with the findings of Brautbar and Howard [42] in humans. Animal studies have shown that phosphine can inhibits the mitochondrial cytochrome oxidase and causes fluctuations in glucose levels secondary to changes in electrolyte and hormones [42]. The increase in plasma total bilirubin concentrations of rats treated with aluminium phosphide are in accordance with the previous study [43].

The increase in blood urea and creatinine in the present study due to aluminium phosphide treatment are in agreement with the results of Misra et al. [44] in humans. The kidney is one of the major targets of phosphine poisoning in the human body [1]. Acute renal failure due to shock could occur [28]. It was found that lipoic acid counteracted the toxic effects of aluminium phosphide on plasma protein, glucose, urea, creatinine and bilirubin. This is in agreement with studies of a similar nature, it has been found that lipoic acid protects against adriamycin [45] and cyclosporine [40] induced nephrotoxicity in rats. In these studies lipoic acid produced its protective effect by preventing the increase in lipid peroxidation level and by restoring the inhibited activities of enzymatic antioxidants and decreased levels of non-enzymatic antioxidants [46].

\section{CONCLUSION}

From the present results, it can be concluded that the exposure of animals to aluminium phosphide is capable of inducing free radicals, marked hazardous alterations in some biochemical characteristics and enzymatic activities. The present study demonstrated the therapeutic effects of lipoic acid administered in combination with aluminium phosphide to minimize its hazardous effects. Co-administration of lipoic acid along with aluminium phosphide attenuates the increase in liver function enzymes and markers of renal injury. On the basis of this study, the usage of lipoic acid may be useful in the protection from aluminium phosphide toxicity in which induced liver and kidney damage. Accordingly, care must be taken into account to avoid mammalian and human exposure to aluminium phosphide and attention should be paid to its sources in foods as well as occupational sources. Also, it should be taken into consideration that supplementation of lipoic acid may act as a protectant against the toxicity of aluminium phosphide.

\section{CONFLICT OF INTEREST}

The authors confirm that this article content has no conflicts of interest.

\section{ACKNOWLEDGEMENTS}

Declared none.

\section{ABBREVIATIONS}

$\begin{array}{lll}\text { AST } & = & \text { Aspartate transaminase } \\ \text { ALT } & = & \text { Alanine transaminase } \\ \text { AlP } & = & \text { Alkaline phosphatase } \\ \text { AcP } & = & \text { acid phosphatase } \\ \text { SOD } & & \text { Superoxide dismutase } \\ \text { CAT } & & \text { Catalase } \\ \text { TBARS } & \text { Thiobarbituric acid reactive substances } \\ \text { GST } & & \text { Glutathione S-transferase } \\ \text { GSH } & & \text { Reduced glutathione }\end{array}$

\section{REFERENCES}

[1] Sudakin DL. Occcupational exposure to aluminium phosphide and phosphine gas? A suspected case report and review of the literature. Hum Exp Toxicol 2005; 24 (1): 27-33.

[2] WHO, World Health Organization. Phosphine and selected metal phosphides Environmental Health Criteria, Geneva, Switzerland, 1988; vol. 73 .

[3] Murali R, Bhalla A, Singh D, Singh S. Acute pesticide poisoning: 15 years experience of a large North-West Indian hospital. Clin Toxicol (Phila) 2009; 47: 35-8.

[4] Mehrpour O, Singh S. Rice tablet poisoning: a major concern in Iranian population. Hum Exp Toxicol 2010; 29: 701-2.

[5] Talukdar R, Signal DK, Tandon RK. Aluminium phosphide induced esophageal stricture. Indian J Gastroenterol 2006; 25(2): 98-9.

[6] Stewart A, Whiteside C, Tyler-Jones C. Phosphine suicide. Chem Incident Rep 2003; 27: 23-6.

[7] Chugh SN, Arora V, Sharma A, Chugh K. Free radical scavengers and lipid peroxidation in acute aluminium phosphide poisoning. Indian J Med Res 1996; 104: 190-3.

[8] Chugh SN, Kolley T, Kakkar R. Chugh K, Sharma A. A critical evaluation of anti-peroxidant effect of intravenous magnesium in acute aluminium phosphide poisoning. Magnes Res 1997; 10(3): 225-30.

[9] Mehrpour O, Jafarzadeh M, Abdollah M. A systematic review of aluminium phosphide poisoning. Arh Hig Rada Toksikol 2012; 63: 61-73.

[10] Abdollahi M, Ranjbar A, Shadnia S, Nikfar S, Rezaie AA. Pesticides and oxidative stress: A review. Med Sci Monit 2004; 10: RA141-RA147. 
[11] Maczurek A, Hager K, Kenklies M, et al. Lipoic acid as an antiinflammatory and neuroprotective treatment for Alzheimer's disease. Adv Drug Deliv Rev 2008; 60: 1463-70.

[12] Hsu CH, Chi BC, Liu MY, Li JH, Chen CJ, Chen RY. Phosphine induced oxidative damage in rats: role of glutathione. Toxicology 2002; 179 (1-2): 1-8.

[13] Dua R, Gill KD. Effect of aluminium phosphide exposure on kinetic properties of cytochrome oxidase and mitochondrial energy metabolism in rat brain. Biochim Biophys Acta 2004; 1674: 4-11.

[14] Cakatay U, Kayali R, Sivas A, Tekeli F. Prooxidant activities of alpha-lipoic acid on oxidative protein damage in the aging rat heart muscle. Arch Gerontol Geriatr 2005; 40: 231-40.

[15] Henry RJ, Cannon DC, Winkelmen W. Clinical Chemistry Principels and Techniques, $11^{\text {th }}$ ed. Happer and Row Publishers 1974.

[16] Trinder P. Determination of glucose in blood using glucose oxidase with an alternative oxygen acceptor. Ann Clin Biochem 1969; 6: 24-7.

[17] Patton CJ, Crouch SR. Sectrophotometric and kinetics investigation of the Berthelot reaction for determination of ammonia. Anal Chem 1977; 49: 464-9.

[18] Pearlman FC, Lee RTY. Detection and measurement of total bilirubin in serum, with use of surfactants as solubilizing agents. Clin Chem 1974; 20: 447-53.

[19] Reitman S, Frankel S. A colorimetric method for the determination of serum glutamic oxalocetic and glutamic pyruvic transaminases. An J Clin Path 1975; 26: 56-63.

[20] Principato GB, Asia MC, Talesa V, Rosi G, Giovannini E, Characterization of the soluble alkaline phosphatase from hepatopancreas of Squilla mantis L. Comp Bioch Physiol 1985; 80: 801-4.

[21] Moss DW. Methods of Enzymatic Analysis, $3^{\text {rd }}$ Ed. (In: Bergmeyer, H.U, Ed). Verlag; Chemie: Weinheim 1984; pp: 92106.

[22] Habig WH, Pabst MJ, Jakoby WB. Glutathione S-transferases. The first enzymatic step in mercapturic acid formation. J Biol Chem 1974; 249: 7130-9.

[23] Luck H. Catalase. In: Bergmayer, MV Ed. Method of Enzymatic Analysis. Verlag Chemic, Academic Press: New York 1974; p. 885 .

[24] Mishra HP, Fridovich I. The role of superoxide anion in the autoxidation of epinephrine and a simple assay for superoxide dismutase. J Biol Chem 1972; 247: 3170-5.

[25] Tappel AL, Zalkin H. Inhibition of lipid peroxidation in mitochondria by vitamin E. Arch Biochem Biophys 1959; 80: 3336.

[26] Beulter E, Duron O, Kelly MB. Improved method for the determination of blood glutathione. J Lab Clin Med 1963; 61: 8828.

[27] Lowry OH, Rosebrough NJ, Farr AL, Randall RJ. Protein measurement with the Folin Phenol Reagent. J Biol Chem 1951; 193: 265-75.

[28] Chugh SN. Aluminium Phosphide in Lall SB, Essentials of Clinical Toxicology. New Delhi: 18 Narosa Publishing House 1998; pp. 416.
[29] Kariman H, Heydari K, Fakhri M, et al. Aluminium phosphide poisoning and oxidative stress: Serum biomarker assessment. J Med Toxicol 2012; 8: 281-4.

[30] Cha'on U, Valmas N, Collins PJ, Reilly PE, Hammock BD, Ebert PR. Disruption of Iron homeostasis increases phosphine toxicity in caenorhabditis elegans. Toxicol Sci 2007; 96(1): 194-201.

[31] Quistad GB, Sparks SE, Casida JE. Chemical model for phosphine induced lipid peroxidation. Pest Manage Sci 2000; 56: 779-83.

[32] Thirunavukkarasu V, Nandhini AT, Anuradha CV. Lipoic acid restores antioxidant system in tissues of hyperinsulinaemic rats. Indian J Med Res 2003; 118: 134-40.

[33] Kokilavani V, Devi MA, Sivarajan K, Panneerselvam C. Combined efficacies of DL-alpha-lipoic acid and meso 2,3 dimercaptosuccinic acid against arsenic induced toxicity in antioxidant systems of rats. Toxicol Lett 2005; 160: 1-7.

[34] Lexis LA, Fassett RG, Coombes JS. Alpla tocopherol and alpha lipoic acid enhance the erythocyte antioxidant defence in cyclosprine A treated rats. Basic Clin Pharmacol Toxicol 2006; 98: 68-73.

[35] Arivazhagan P, Ramanthan K, Panneerselvam C. Effect of DLalpha- lipoic acid on glutathione metabolized enzymes in aged rats. Exp Gernot 2001; 37: 81-7.

[36] Reed LJ. A trail of research from lipoic acid to alpha-keto acid dehydrogenase complexes. J Biol Chem 2001; 276: 38329-36.

[37] Henriksen EJ. Exercise training and the antioxidant alpha-lipoic acid in the treatment of insulin resistance and type 2 diabetes. Free Radic Biol Med 2006; 40: 3-12.

[38] Gawish AM. The protective role of alpha lipoic acid against pesticides induced testicular toxicity- histopathological and histochemical studies. J Aquac Res Develop 2010; 1: 101.

[39] Saleki S, Ardalan FA, Javidan-Nejad A. Liver histopathology of fatal phosphine poisoning. Forensic Sci Int 2007; 166: 190-3.

[40] Amudha G, Josephine A. Role of lipoic acid in reducing the oxidative stress induced by cyclosporine A. Clin Chim Acta 2006; 372 (1-2): 134-9.

[41] Sivaprasad R, Nagaraj M, Varalakshmi P. Combined efficacies of lipoic acid and 2,3-dimercaptosuccinic acid against lead-induced lipid peroxidation in rat liver. J Nutr Biochem 2004; 15: 18-23.

[42] Brautbar N, Howard J. Phosphine toxicity: report of two cases and review of the literature. Toxicol Ind Health 2002; 18: 71-5.

[43] Singh S, Singh D, Wig N. Aluminium phosphide ingestion - A clinicopathological study. Clin Toxicol 1996; 34: 703-7.

[44] Misra UK, Tripathi AK, Pandey R, Bhargwa B. Acute phosphine poisoning following ingestion of aluminium phosphide. HumToxicol 1988; 7: 343-5.

[45] Malarkodi KP, Balachandar AV, Varalakshmi P. The influence of lipoic acid on adriamycin-induced hyperlipidemic nephrotoxicity in rats. Mol Cell Biochem 2003; 247(1-2): 139-5.

[46] Abdel-zaher AO, Abdel-Hady RH, Mahmoud MM, Farrag MMY. The potential protective role of alpha-lipoic acid against acetaminophen-induced hepatic and renal damage. Toxicology 2008; 243: 261-70.

(C) Yousef et al.; Licensee Bentham Open.

This is an open access article licensed under the terms of the Creative Commons Attribution Non-Commercial License (http://creativecommons.org/licenses/ by-nc/3.0/) which permits unrestricted, non-commercial use, distribution and reproduction in any medium, provided the work is properly cited. 